\title{
Antimicrobial Resistance Profiles of Diarrheagenic E. coli (DEC) and Salmonella Species Recovered from Diarrheal Patients in Selected Rural
} Communities of the Amathole District Municipality, Eastern Cape Province, South Africa

This article was published in the following Dove Press journal: Infection and Drug Resistance

\author{
Luyanda Msolo (D) ${ }^{1,2}$ \\ Benson C Iweriebor ${ }^{3}$ \\ Anthony I Okoh (D) ${ }^{1,2}$ \\ 'SAMRC Microbial Water Quality \\ Monitoring Centre, University of Fort \\ Hare, Alice, Eastern Cape, South Africa; \\ ${ }^{2}$ Applied and Environmental Microbiology \\ Research Group, Department of \\ Biochemistry and Microbiology, \\ University of Fort Hare, Alice, Eastern \\ Cape, South Africa; ${ }^{3}$ Sefako Makgatho \\ Health Sciences University, Ga-rankuwa, \\ Pretoria, Gauteng, South Africa
}

Correspondence: Luyanda Msolo Applied and Environmental Microbiology Research Group, Department of Biochemistry and Microbiology, University of Fort Hare, Alice, Eastern Cape 5700, South Africa

Tel +27638965674

Email LMsolo@ufh.ac.za
Purpose: The emergence of multidrug-resistant bacteria remains as one of the major impediments towards the prevention and treatment of microbial infections and continues to be a serious threat to medicine. Henceforth, this study aimed at elucidating the antimicrobial resistance profiles of diarrheagenic E. coli (DEC) and Salmonella species recovered from diarrheal patients in selected rural communities of the Amathole District Municipality (ADM), Eastern Cape Province, South Africa (SA).

Methods: The antimicrobial resistance profiles of diarrheagenic E. coli (DEC) and Salmonella isolates were evaluated using antimicrobial susceptibility tests and the relevant antimicrobial resistance factors were elucidated by the Polymerase Chain Reaction technique.

Results: A sum of 324 diarrheagenic E. coli (DEC) and 62 Salmonella isolates were recovered from diarrheal stool specimens collected amongst diarrheal patients admitted in medical facilities/health-care centers within the ADM in the Eastern Cape Province, South Africa. Multiple antimicrobial resistance index mean values of 0.7 and 0.5 for DEC and Salmonella isolates, respectively, were observed in this study, indicating that these isolates were from sources where antimicrobials were frequently used. The antimicrobial resistance factors $a m p C$, bla $a_{T E M}$, SulI and II, tet A and aadA were detected among antimicrobialresistant DEC pathotypes and Salmonella isolates recovered in this study.

Conclusion: The occurrence of the multiple antimicrobial-resistant DEC and Salmonella isolates with the relevant antimicrobial resistance factors in this study suggests a portentous human health threat associated with diarrhea and a major deterrent in medicine.

Keywords: diarrheagenic E. coli, Salmonella, antimicrobials, resistance

\section{Introduction}

Bacterial infections remain as one of the elite causes of morbi-mortalities in children due to the disease burden brought upon by such infections, and the emergence of antimicrobial resistance to prevailing antimicrobials used for the treatment of such infections exacerbates this disease burden. ${ }^{1}$

The ability of microorganisms to repel the action of a particular antimicrobial agent is referred to as antimicrobial resistance (AMR), and this phenomenon has been 
noticeably increasing over the years. As a result, over 2 million people acquire antimicrobial-resistant infections which account for over 23,000 lives each year which makes it one of the most worrisome public health encumbrance. ${ }^{2}$ Moreover, the accumulative prevalence of infections caused by pathogenic $E$. coli variants producing extended-spectrum b-lactamases (ESBL's) among other bacteria, disputes the utilization of third-generation cephalosporins in clinical therapy as these antimicrobials have become excessively sedentary against infections caused by these pathogens. ${ }^{3}$

Antimicrobial resistance remains a serious health and economic hindrance especially in the less fortunate countries in Africa, and because of the escalated disease burden and the cost restraints, which tend to impede a more revolutionized applications and the invention of efficient agents as an alternative for the existing less efficient agents. ${ }^{4}$ Also, the immeasurable impact that antibiotics have brought about in modern life can never be overemphasized as they have shaped our world in so many positive ways across different sectors in medicine, agriculture and food industry. However; exploitative use of these antimicrobials increases selective pressure and thereby promoting the accumulation of antimicrobial-resistant bacteria, which are becoming a troublesome threat to public health. ${ }^{5}$ Furthermore, the accumulation of antimicrobial resistance (AR) in pathogenic bacteria including $E$. coli and Salmonella species over the years continues to confront the efficacy of antimicrobials, thereby crippling the advancements towards the treatment of infections worldwide, hence making it almost impossible to combat development of infectious diseases in clinical, public and environmental health systems. ${ }^{6}$ In this paper, we report on antimicrobial resistance profiles of DEC and Salmonella isolates recovered from diarrheal patients within the rural communities of the ADM in the Eastern Cape Province, South Africa.

\section{Materials and Methods Study Site}

Regardless of its rural hinterlands, the ADM has a relatively high populace of over 880790 thousand people which covers $12 \%$ of the overall population of the province. Significant improvements have been made over the years concerning water and sanitation in the region. However, about $32.21 \%$ of households still have no formal piped water; they access water from natural water sources including dams, rivers, lakes, etc and household sanitation still have significant challenges as far as sanitation in Amathole is concerned, recording an appallingly high rate of households with no sanitation. ${ }^{7,8}$

\section{Sample Collection}

Stool specimens were collected from partaking patients who presented mild to severe diarrheal symptoms and were admitted in private or public hospitals and clinics. Samples were collected in sterile screw-capped $50 \mathrm{~mL}$ size centrifuge tubes $\left(\right.$ Lasec $^{\circledR}$, South Africa) over a period of 22 months (February 2017-November 2018) and were transported on ice-packs to the Applied and Environmental Microbiology Research Group (AEMREG) research laboratory at the University of Fort Hare, for analyses immediately on arrival. Stool specimens were analyzed for the presence of DEC and Salmonella species.

\section{Isolation of Salmonella Spp}

Stool specimens were inoculated into $10 \mathrm{~mL}$ of Rappaport Vassiliadis broth (Oxoid ${ }^{\mathrm{TM}} \mathrm{CM} 0669$, SA) and incubated at $42{ }^{\circ} \mathrm{C}$ for $18-24$ hours. After incubation, Xylose- LysineDesoxycholate (XLD) agar (Oxoid ${ }^{\mathrm{TM}} \mathrm{CM} 0469$, SA) plates were used for the detection and isolation of Salmonella species and were incubated at $37{ }^{\circ} \mathrm{C}$ for at least $18-24$ hours. Phenotypic red to pink colonies with black centers were picked as presumptive Salmonella isolates. ${ }^{9}$

\section{Isolation of Diarrheagenic E. coli (DEC)}

Stool specimens were inoculated onto sterile Tryptone Soy Broth (TSB) (Oxoid ${ }^{\mathrm{TM}}$ CM0129, SA) for the enrichment and incubated in a shaker at $37^{\circ} \mathrm{C}$ for at least $18-24$ hours. After incubation, turbid cultures were further subcultured on chromogenic agar (CONDA, Pronadisa, SA) for the detection of DEC pathotypes and incubated at $37{ }^{\circ} \mathrm{C}$ for at least 18-24 hours. Typical blue colonies were picked as presumptive DEC isolates. ${ }^{10}$

\section{Identification of the Presumptive DEC and Salmonella Isolates}

The modified boiling method as previously described by ${ }^{11}$ was used to extract genomic DNA from the presumptive isolates. A distinct colony of the isolates were suspended into sterile Tryptone Soy Broth (TSB) (Oxoid ${ }^{\mathrm{TM}}$ CM0129, SA) and incubated at $37^{\circ} \mathrm{C}$ for at least $18-24$ hours. About $1.5 \mathrm{~mL}$ aliquots from the turbid culture was centrifuged at $12,000 \mathrm{r} / \mathrm{min}$ for 10 minutes to pellet the cells. The resultant pellet was then washed twice using sterile-distilled 
Table I Primer Sequences for the Confirmation of Diarrheagenic E. coli and Salmonella Isolates

\begin{tabular}{|l|l|l|l|l|l|l|}
\hline Bacteria & Primer(s) & Primer Sequence (5'-3') & $\begin{array}{l}\text { Amplicon } \\
\text { Size (bp) }\end{array}$ & $\begin{array}{l}\text { PCR Cycling } \\
\text { Conditions }\end{array}$ & Cycles & Reference(s) \\
\hline $\begin{array}{l}\text { Diarrheagenic } \\
\text { E. coli }\end{array}$ & uidA & $\begin{array}{l}\text { F: AAA ACG GCA AGA AAAAGC AG } \\
\text { R:ACGCGTGGTTAACAGTCTTGCG }\end{array}$ & 147 & $\begin{array}{l}94^{\circ} \mathrm{C}(5 \mathrm{mins}), 95^{\circ} \mathrm{C}(30 \\
\text { secs }), 58^{\circ} \mathrm{C}(60 \mathrm{secs}), 72^{\circ} \\
\mathrm{C}(60 \mathrm{secs}), 72^{\circ} \mathrm{C}(8 \mathrm{mins})\end{array}$ & 35 & {$[12]$} \\
\hline Salmonella spp. & $\begin{array}{l}\text { ompC } \\
\text { invA }\end{array}$ & $\begin{array}{l}\text { F: ATCGCTGAC TTATGCAAT } \\
\text { R: CGG GTTGCGTTATAGGTC } \\
\text { F: TATCGCCACGTTCGGGCA } \\
\text { R:TCGCACCGTCAAAGGAAC }\end{array}$ & 204 & $\begin{array}{l}95^{\circ} \mathrm{C}(1 \mathrm{~min}), 95^{\circ} \mathrm{C}(20 \\
\mathrm{secs}), 57^{\circ} \mathrm{C}(15 \mathrm{secs}), 72^{\circ} \\
\mathrm{C}(2 \mathrm{mins}), 72^{\circ} \mathrm{C}(7 \mathrm{mins})\end{array}$ & 35 & $\begin{array}{l}{[13]} \\
{[14]}\end{array}$ \\
\hline
\end{tabular}

Abbreviations: Mins, minutes; Secs, seconds.

water before re-suspending into $200 \mu \mathrm{L}$ of sterile-distilled water. The suspension was boiled at $100^{\circ} \mathrm{C}$ for 10 minutes in a Dri-Block ${ }^{\circledR}$ DB-3D $\left(\right.$ Lasec $\left.^{\circledR}, \mathrm{SA}\right)$. The boiled cell lysate was cooled and centrifuged at 13,000 r/min for 5 min. The supernatant was aseptically transferred into sterile micro-centrifuge tubes and used as template DNA in PCR.PCR amplification for the confirmation DEC and Salmonella spp. was performed on a thermal cycler

Table 2 A Panel of Commercial Antimicrobial Disc Used for Susceptibility Testing of Diarrheagenic E. coli Isolates

\begin{tabular}{|c|c|}
\hline Antibiotic Class & Antimicrobial Agent (Potency) \\
\hline Aminoglycosides & $\begin{array}{l}\text { Gentamicin }(10 \mu g) \\
\text { Amikacin }(30 \mu g)\end{array}$ \\
\hline Fluoroquinolones & Norfloxacin $(10 \mu g)$ \\
\hline Carbapenems & $\begin{array}{l}\text { Imipenem }(10 \mu g) \\
\text { Meropenem }(10 \mu g)\end{array}$ \\
\hline Polymyxins & Polymyxin B (300 units) \\
\hline Penicillins & $\begin{array}{l}\text { Penicillin G (10 } \mu \mathrm{g}) \\
\text { Ampicillin }(10 \mu \mathrm{g}) \\
\text { Amoxicillin }(10 \mu \mathrm{g})\end{array}$ \\
\hline Macrolides & Erythromycin ( $15 \mu \mathrm{g})$ \\
\hline Cephems & $\begin{array}{l}\text { Ceftazidime }(30 \mu \mathrm{g}) \\
\text { Cefotaxime }(30 \mu \mathrm{g}) \\
\text { Cephalothin }(30 \mu \mathrm{g})\end{array}$ \\
\hline Phenicols & Chloramphenicol $(30 \mu g)$ \\
\hline Nitrofurantoin & Nitrofurantoin $(200 \mu g)$ \\
\hline Foliate Pathways & Trimethoprim-sulfamethoxazole $(25 \mu \mathrm{g})$ \\
\hline Quinolones & Nalidixic Acid (30 $\mu \mathrm{g})$ \\
\hline Tetracyclines & $\begin{array}{l}\text { Tetracycline }(30 \mu \mathrm{g}) \\
\text { Doxycycline }(30 \mu \mathrm{g})\end{array}$ \\
\hline
\end{tabular}

(BIORAD, T100 ${ }^{\mathrm{TM}}$ thermal cycler, SA) using genusspecific primers (Table 1). PCR amplicons were then visualized by gel electrophoresis on $2 \%$ agarose (Separations, SA) stained with $5 \mu \mathrm{L}$ ethidium bromide. 100 bp DNA ladder was used as genetic markers.

\section{Antimicrobial Resistance Profiling}

Antimicrobial resistance profiles of DEC and Salmonella isolates were determined by the standard disc diffusion method of Kirby-Bauer as described by the Clinical and Laboratory Standards Institute. ${ }^{15}$ DEC and Salmonella isolates were screened for resistance against a pool of 19 and 12 antibiotics (Tables 2 and 3), respectively, belonging to different families of antimicrobials (Mast Diagnostics, United Kingdom). Pure isolates previously grown on sterile nutrient agar were inoculated on sterile physiological-buffered saline

Table 3 A Panel of Commercial Antimicrobial Disc Used for Susceptibility Testing of Salmonella Isolates

\begin{tabular}{|c|c|}
\hline Antibiotic Class & Antimicrobial Agent (Potency) \\
\hline Penicillins & $\begin{array}{l}\text { Ampicillin }(10 \mu g) \\
\text { Amoxicillin }(10 \mu g)\end{array}$ \\
\hline Macrolides & Azithromycin ( $15 \mu \mathrm{g})$ \\
\hline Cephems & $\begin{array}{l}\text { Ceftriaxone }(30 \mu \mathrm{g}) \\
\text { Cephalothin }(30 \mu \mathrm{g}) \\
\text { Cefotaxime }(30 \mu \mathrm{g})\end{array}$ \\
\hline Carbapenems & Imipenem (10 $\mu \mathrm{g})$ \\
\hline Monobactams & Aztreonam $(30 \mu \mathrm{g})$ \\
\hline Folate pathway antagonist & Trimethoprims $(25 \mu \mathrm{g})$ \\
\hline Aminoglycoside & Streptomycin ( $10 \mu \mathrm{g})$ \\
\hline Fluoroquinolones & Ciprofloxacin (5 $\mu \mathrm{g})$ \\
\hline Tetracyclines & Tetracycline $(30 \mu \mathrm{g})$ \\
\hline
\end{tabular}


(PBS) solution $(0.85 \% \mathrm{NaCl})$ to make up a bacterial suspension with a density equivalent to $0.5 \mathrm{McFarland}$ standards. Sterile cotton swab-stick (Copan, Italy) was stroke into the suspension and spread uniformly onto the entire surface of the Mueller Hinton agar plates. Relevant antibiotic discs were placed on the surface of the inoculated plates using a disc dispenser (Mast Diagnostics, UK) and were incubated at $37{ }^{\circ} \mathrm{C}$ for $18-24$ hours. The diameters of the zones inhibition were measured to the nearest millimeter and recorded. Individual isolate was characterized as resistant (R), intermediate (I) and susceptible (S) to antimicrobials based on the diameter of the zones of inhibition and interpreted according to the standards recommended by the $\mathrm{CLSI}^{15}$ to generate the antimicrobial profiles of the isolates.

\section{Multiple Antimicrobial-Resistant Phenotypes (MARPs)}

The multiple antimicrobial-resistant phenotypes were generated according to the method as previously described by Kinge et al $^{16}$ where isolates that exhibited resistance to more than 2 antibiotics were assessed. The resistant patterns and the frequencies of antibiotics to which individual isolates were resistant to, were generated from the results of the antimicrobial resistance test.

\section{Multiple Antimicrobial Resistance Index (MARI)}

Multiple antimicrobial resistance indices (MARI) for both DEC and Salmonella isolates were generated using the mathematical expression as described by Blasco et $\mathrm{al}^{17}$ which is expressed as:

MAR index $=a / b$,

where "a" represents the number of antibiotics to which an individual isolate is resistant to and " $b$ " the sum of antibiotics to which individual isolate was tested.

\section{Detection of Antimicrobial Resistance}

\section{Genes}

All DEC and Salmonella isolates that exhibited phenotypical antimicrobial resistance were screened for the presence of relevant antimicrobial resistance genes by conventional PCR amplification. Isolates that were resistant against Sulfonamides were screened for resistance genes sulI and sulII; $\beta$-lactams (ampC and bla $\left.a_{T E M}\right)$; Tetracyclines (tet $A$ ) and Aminoglycosides (aadA). Table 4 shows the oligonucleotide sequences, thermal cycling conditions and amplicon sizes for the target resistance genes. All PCR tests were performed on a thermo-cycler (BIORAD, T100 ${ }^{\mathrm{TM}}$ thermal cycler, SA) and the PCR amplicons were analyzed by gel electrophoresis resolved on $2 \%$ agarose gels (Separations, SA) stained with $5 \mu \mathrm{L}$ ethidium bromide. A 100-bp gene ruler (New England Biolabs Inc., United States of America) was used as a molecular marker for estimation of DNA band sizes, $0.5 \mathrm{X}$ TBE buffer was used for the electrophoresis at $100 \mathrm{~V}$ for 50-60 min, and visualized by UVITEC (Alliance 4.7, France).

Table 4 Oligonucleotides Sequences for the Detection of Resistance Gene Determinants

\begin{tabular}{|c|c|c|c|c|c|c|}
\hline $\begin{array}{l}\text { Antimicrobial } \\
\text { Family }\end{array}$ & $\begin{array}{l}\text { Target } \\
\text { Gene }\end{array}$ & Primer Sequence $\left(5^{\prime} \rightarrow 3^{\prime}\right)$ & $\begin{array}{l}\text { Amplicon } \\
\text { Size (bp) }\end{array}$ & PCR Cycling Condition & Cycles & $\begin{array}{l}\text { Reference } \\
\text { (s) }\end{array}$ \\
\hline \multirow[t]{2}{*}{ Beta-lactams } & $a m p C$ & $\begin{array}{l}\text { F:TTCTATCAAMACTGGCAR } \\
\text { R:CCYTTTTATGTACCCAYG }\end{array}$ & 550 & $\begin{array}{l}94^{\circ} \mathrm{C}(4 \text { mins }), 94^{\circ} \mathrm{C}(45 \text { secs }), 60^{\circ} \mathrm{C}(45 \\
\text { secs }), 72^{\circ} \mathrm{C}(45 \text { secs }), 72^{\circ} \mathrm{C}(7 \text { mins })\end{array}$ & 30 & {$[18]$} \\
\hline & $B l a_{\text {TEM }}$ & $\begin{array}{l}\text { F:TTTCGTGTCGCCCTTATTC } \\
\text { R:CCGGCTCCAGATTTATCA }\end{array}$ & 690 & $\begin{array}{l}95^{\circ} \mathrm{C}(5 \text { Mins }), 94^{\circ} \mathrm{C}(30 \text { secs }), 60^{\circ} \mathrm{C}(30 \\
\text { secs }), 72^{\circ} \mathrm{C}(90 \text { secs }), 72^{\circ} \mathrm{C}(5 \text { mins })\end{array}$ & 30 & [19] \\
\hline \multirow[t]{2}{*}{ Sulfonamides } & sull & $\begin{array}{l}\text { F: TTCGGCATTCTGAATCTC } \\
\text { R: ATGATCTAACCCTCGGT }\end{array}$ & 822 & $\begin{array}{l}94^{\circ} \mathrm{C}(5 \text { mins }), 94^{\circ} \mathrm{C}(60 \text { secs }), 55^{\circ} \mathrm{C}(60 \\
\text { secs }), 72^{\circ} \mathrm{C}(5 \text { mins }), 72^{\circ} \mathrm{C}(5 \text { mins })\end{array}$ & 35 & [20] \\
\hline & sullı & $\begin{array}{l}\text { F: CGGCATCGTCAACATAA } \\
\text { R: GTGTGCGGATGAAGTCA }\end{array}$ & 625 & $\begin{array}{l}94^{\circ} \mathrm{C}(5 \text { mins }), 94^{\circ} \mathrm{C}(30 \text { secs }), 50^{\circ} \mathrm{C}(30 \\
\text { secs }), 72^{\circ} \mathrm{C}(90 \text { secs }), 72^{\circ} \mathrm{C}(5 \text { mins })\end{array}$ & 30 & {$[21]$} \\
\hline Tetracyclines & Tet A & $\begin{array}{l}\text { F: GCTACATCCTGCTTGCCT } \\
\text { R: CATAGATCGCCGTGAAG }\end{array}$ & 201 & $\begin{array}{l}94^{\circ} \mathrm{C}(5 \text { mins }), 94^{\circ} \mathrm{C}(60 \text { secs }), 55^{\circ} \mathrm{C}(60 \\
\text { secs }), 72^{\circ} \mathrm{C}(90 \text { secs }), 72^{\circ} \mathrm{C}(5 \text { mins })\end{array}$ & 35 & [22] \\
\hline Aminoglycosides & $\operatorname{aadA}$ & $\begin{array}{l}\text { F: GTGGATGGCGGCCTGAA } \\
\text { R: AATGCCCAGTCGGCAGC }\end{array}$ & 525 & $\begin{array}{l}94^{\circ} \mathrm{C}(4 \text { mins }), 94^{\circ} \mathrm{C}(45 \text { secs }), 50^{\circ} \mathrm{C}(45 \\
\text { secs }), 72^{\circ} \mathrm{C}(45 \text { secs }), 72^{\circ} \mathrm{C}(7 \text { mins })\end{array}$ & 30 & {$[18]$} \\
\hline
\end{tabular}

Abbreviations: Mins, minutes; Secs, seconds. 


\section{Results}

\section{Identification of Presumptive DEC and Salmonella Isolates}

A total of $324(82 \%)$ diarrheagenic E. coli and $62(23 \%)$ Salmonella isolates were positively identified by polymerase chain reaction amplification of the genus-specific primer set uidA (147 bp) for E. coli and two sets of Salmonella genusspecific primers $i n v A$ (275 bp) and $\operatorname{ompC}(204 \mathrm{bp}$ ). Figures 1 and 2 represent the gel electrophoresis images of the confirmed DEC and Salmonella isolates, respectively.

\section{Antimicrobial Resistance Profiling}

The antimicrobial resistance profiles of DEC and Salmonella isolates revealed high levels of resistance against more than one antimicrobial. Diarrheagenic $E$. coli isolates were tested against 19 commercial antimicrobial agents, where maximum susceptibilities were observed against Amikacin (95\%), Gentamycin (93\%), Meropenem (91\%), Chloramphenicol (90\%), Norfloxacin (88\%), Nitrofurantoin (87\%), imipenem (84\%), Polymyxin B (83\%), Ceftazidime, Cefotaxime, Cephalothin, and Nalidixic Acids demonstrated susceptibilities slightly above average (62, 55, 62 and 58\%, respectively). Even so; multiple isolates exhibited multidrug resistances with a maximum resistance demonstrated against Penicillin G (100\%), Ampicillin (87\%), Amoxicillin (86\%), Tetracycline (84\%), Doxycycline (82\%), Trimethoprim/ Sulphamethoxazole (82\%) and Erythromycin (75\%). Additionally, some isolates revealed resistance rates below average which ranged from $39 \%$ to a minimum of $1 \%$. A panel of 12 antibiotics from 9 families that are used to treat infections caused by Salmonella isolates were tested for their antimicrobial susceptibilities. Salmonella isolates portrayed maximum susceptibility (100\%) against tetracycline, Aztreonam, and Ceftriaxone, peak susceptibility rates were also observed against Cefotaxime (98\%), Imipenem (97\%), trimethoprim (73\%) and Streptomycin which was the only antimicrobial slightly above average with 53\% susceptibility; other antimicrobials demonstrated susceptibilities below average. Interestingly, the Salmonella isolates presented unusually extreme resistance rates against Cephalothin (98\%) and Amoyxcilin (95\%), and relatively high resistance was observed against Azithromycin (61\%).

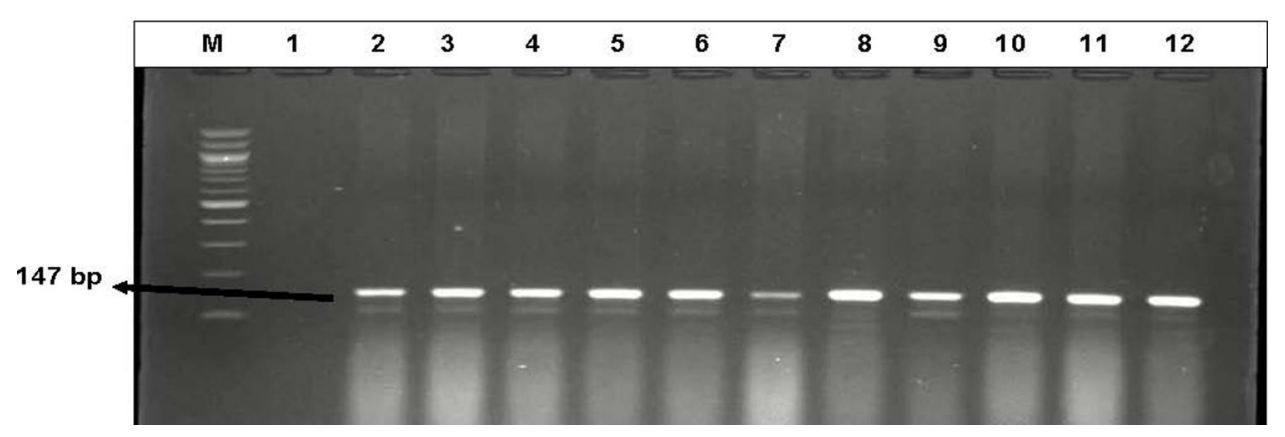

Figure I Representative Gel electrophoresis image of the confirmed DEC isolates recovered from diarrheagenic stool specimens. Lane (M) Molecular weight marker (I00 bp DNA ladder, Thermo Scientific), lane I: negative control, lane 2 to I2: Some of the positive diarrheagenic E. coli isolates.

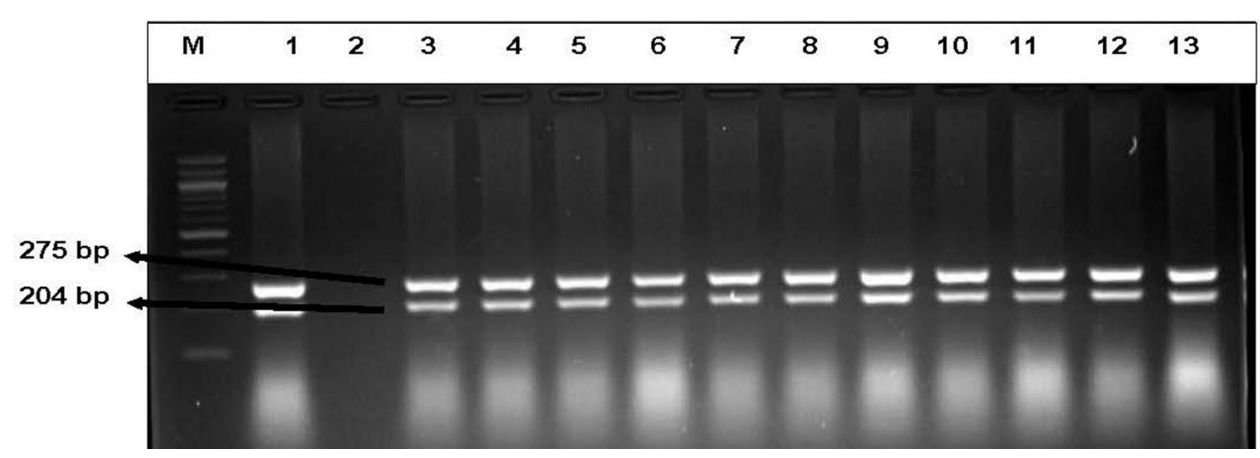

Figure 2 Representative Gel electrophoresis image of the confirmed Salmonella isolates recovered from diarrheagenic stool specimens. Lane (M) Molecular weight marker (I00 bp DNA ladder, Thermo Scientific), lane I: positive control S. enterica subsp. Typhimurium (DSMZ I4028), lane 2: negative control, lane 3 to I3: Some of the positive Salmonella isolates. 


\section{Multiple Antimicrobial-Resistant Phenotypes (MARPs)}

The multiple antibiotic-resistant phenotypes of the confirmed DEC and Salmonella spp., revealed that 85 and $65 \%$ of the antimicrobial-resistant DEC and Salmonella isolates, respectively, were resistant against 3 or more antimicrobial agents. The occurrence of multiple antimicrobialresistant $D E C$ was observed in three, five, six, eight, nine, ten, eleven and thirteen antimicrobials (Table 5), while Salmonella isolates demonstrated their prevalence of multiple antimicrobial resistances against three, four, five and six antimicrobials (Table 6).

\section{Multiple Antimicrobial Resistance Index (MARI)}

The multiple antimicrobial resistance indices of the DEC and Salmonella isolates were found to be above the acceptable 0.2 threshold value, these microbes presented average MARIs of 0.7 and 0.5 respectively. In principle, these findings reveal inappropriate use of antimicrobials in the region which poses a significant therapeutic setback and consequently, public health burden.

\section{Detection of Antimicrobial Resistance Determinants in DEC and Salmonella}

\section{Isolates}

Among the Beta-lactams; ampC (47\%) and blaTEM (33\%) were the only resistance determinants detected amongst DEC isolates. In almost all the DEC isolates that were resistant against Sulfanomides, sulI (62\%) was the most detected compared to sulII (18\%) resistant genes. Only $6 \%$ of the antimicrobial-resistant Salmonella isolates harbored sulII resistance gene. Among the Tetracycline-resistant DEC isolates; tet $\mathrm{A}$ was the sole resistance gene detected in $93 \%$ of the isolates. The aadA resistance gene was also the sole gene detected in 24 and $39 \%$ of the Aminoglycoside-resistant DEC and Salmonella isolates, respectively. Figures 5-8 represent gel electrophoresis images for the detection of resistance genetic factors from the antimicrobial-resistant DEC and Salmonella isolates.

$\beta$-Lactams are widely used antimicrobials everywhere in the world hence their efficacies are undermined by numerous bacterial infections. Evidently so; maximum resistance patterns to more than 2 antimicrobials by DEC isolates were observed in this study. Conversely;
Table 5 Patterns of Multiple Antibiotic-Resistance Phenotypes (MARPs) of Diarrheagenic E. coli

\begin{tabular}{|c|c|c|}
\hline \multicolumn{3}{|c|}{ Diarrheagenic E. coli $(n=324)$} \\
\hline $\begin{array}{l}\text { No. of } \\
\text { Antimicrobials }\end{array}$ & Resistance Pattern & $\begin{array}{l}\text { No. } \\
\text { Observed }\end{array}$ \\
\hline \multirow[t]{3}{*}{3} & AP-A-PG & 4 \\
\hline & AP-PG-TS & 2 \\
\hline & AP-PG-E & 2 \\
\hline \multirow[t]{4}{*}{5} & KF-PB-E-PG-DXT & 3 \\
\hline & AP-PG-E-AM-T & 5 \\
\hline & AP-PG-E-T-DXT & I \\
\hline & AP-PG-A-TS-T & I \\
\hline \multirow[t]{9}{*}{6} & AP-PG-CIP-E-A-TS & 2 \\
\hline & AP-PG-CXM-E-A-T & 8 \\
\hline & AP-PG-CIP-CXM-PB-DXT & 4 \\
\hline & AP-PG-E-A-TS-T & 7 \\
\hline & PG-CXM-PB-TS-T-DXT & I \\
\hline & AP-NOR-PB-E-DXT & 4 \\
\hline & AP-PG-AK-KF-E-CAZ-CTX & II \\
\hline & AP-PG-KF-CAZ-TS-T & 4 \\
\hline & AP-PGAK-E-A-CTX & 6 \\
\hline \multirow[t]{2}{*}{8} & AP-PG-E-A-CTX-TS-T-DXT & 12 \\
\hline & PG-KF-PB-E-A-TS-T-DXT & I \\
\hline \multirow[t]{5}{*}{9} & AP-PG-NOR-A-CTX-TS-NA & 6 \\
\hline & $-\mathrm{T}-\mathrm{D} \times \mathrm{T}$ & \\
\hline & AP-PG-E-A-PB-C-TS-T-DXT & I \\
\hline & AP-PG-A-GM-NOR-NI-TS & I \\
\hline & -T-DXT & \\
\hline \multirow[t]{13}{*}{10} & AP-PG-KF-NOR-E-A-CTX-TS & I \\
\hline & $-\mathrm{T}-\mathrm{DXT}$ & \\
\hline & AP-PG-KF-E-A-CTX-C-TS- & 4 \\
\hline & T-DXT & \\
\hline & AP-PG-KF-PB-E-CAZ-C-A-TS- & I \\
\hline & NA & \\
\hline & AP-PG-KF-NOR-PB-E-CAZ- & I \\
\hline & A-CTX-T & \\
\hline & AP-PG-NOR-CXM-E-CAZ- & 1 \\
\hline & A-CTX-TS-DXT & \\
\hline & AP-PG-AK-PG-PB-E-CAZ- & 3 \\
\hline & A-NA-CTX & \\
\hline & AP-PG-AK-PB-E-NI-A-CTX-TS & 5 \\
\hline II & PG-KF-PG-A-E-TS-T-DXT-NA- & 2 \\
\hline 13 & $\begin{array}{l}\text { PG-KF-PG-A-E-T-DXT-NA-C-NI- } \\
\text { CTX-PB-TS }\end{array}$ & I \\
\hline
\end{tabular}

Abbreviations: AP, ampicillin; GM, gentamycin; $A K$, amikacin; $K F$, cephalothin; NOR, norfloxacin; IMI, imipenem; PB, polymyxin B; PG, penicillin G; E, erythromycin; CAZ, ceftazidime; MEM-S, meropenem; CTX, cefotaxime; C, chloramphenicol; $\mathrm{NI}$, nitrofurantoin; TS, trimethoprim/sulphamethaxazole; NA, nalidixic Acid; T, tetracycline; DXT, doxycline; A, amoyxcilin. 
Table 6 Patterns of Multiple Antibiotic-Resistance Phenotypes (MARPs) of Salmonella Isolates

\begin{tabular}{|l|l|l|}
\hline \multicolumn{2}{|l|}{ Salmonella Isolates (n=62) } \\
\hline No. of Antimicrobials & Resistance Pattern & No. Observed \\
\hline 3 & AP-KF-A & 2 \\
& S-KF-A & 4 \\
& ATH-KF-A & 15 \\
& AP-S-KF & 1 \\
& ATH-TM-A & 1 \\
\hline 4 & ATH-S-KF-A & 1 \\
& ATH-TM-KF-A & 1 \\
& ATH-CIP-KF-A & 1 \\
& AP-ATH-KF-A & 4 \\
& AP-S-KF-A & 2 \\
& TM-S-KF-A & 1 \\
\hline 5 & AP-ATH-S-KF-A & 2 \\
& AP-TM-S-KF-A & 2 \\
\hline 6 & AP-ATH-TM-KF-A & 2 \\
\hline & AP-ATH-TM-S-KF-A & 6 \\
& ATH-TM-S-KF-A & 1 \\
\hline
\end{tabular}

Abbreviations: AP, ampicillin; ATH, azithromycin; CRO, ceftriaxone; IMI, imipenem; ATM, aztreonam; TM, trimethoprim; CTX, cefotaxime; S, streptomycin; CIP, ciprofloxacin; KF, cephalothin; A, amoyxcilin; T, tetracycline.

Salmonella isolates demonstrated maximum resistance against amoxicillin and slightly below average for ampicillin. Among the screened $\beta$ - Lactam-resistance determinants, only $a m p \mathrm{C}$, and $b l a_{\mathrm{TEM}}$ antimicrobial resistance genes were detected in $47 \%$ and $33 \%$ of the $\beta$ - lactamaseresistant diarrhoeagenic $E$. coli isolates, respectively) and only ampC was detected in $41 \%$ of Salmonella isolates (Figures 3 and 4).

Among the aminoglycoside-resistance determinants, $\operatorname{aadA}$ was the predominant resistance gene detected in $39 \%$ of the Salmonella isolates that demonstrated resistance against aminoglycosides. Moreover, aadA was conversely expressed in few diarrheagenic $E$. coli isolates
(24\%) which were resistant against aminoglycosides. No other resistance determinants were detected. Also, the coexpression of the aforementioned resistance gene in both DEC and Salmonella isolates suggests a possible horizontal gene transmission since they were isolated from the same diarrheagenic stool specimens. Figure 5 shows the gel electrophoresis illustration of the aadA gene amplicons from some of the aminoglycoside-resistant DEC and Salmonella isolates.

Diarrheagenic E. coli exhibited peak resistance rates of $82 \%$ against the class of Sulfonamides antimicrobials, whereas only $27 \%$ resistance rates were generated among Salmonella isolates. The antimicrobial resistance gene sulI was the most prevalent resistance gene detected in $62 \%$ compared to sulII which was detected in $18 \%$ of the sulfonamide-resistant DEC isolates. However, sulII was the only resistance gene detected in $6 \%$ of the sulfonamide-resistant Salmonella species. Figures 6 and 7 represent the gel electrophoresis images of SulI (822 bp) and SulII (625 bp) resistance genes amplicons.

Tetracyclines were among the predominant antimicrobials after penicillins to which diarrheagenic E. coli isolates demonstrated peak resistance against ie tetracycline $(84 \%)$ and doxycycline (82\%). Among the resistance determinants screened, tet $A$ was the sole resistance gene detected in $93 \%$ of the tetracycline-resistant DEC isolates (Figure 8). Salmonella isolates were all susceptible to the tetracyclines.

\section{Discussion}

In the present study, Salmonella isolates demonstrated a much higher resistance rate against Cephalothin (98\%), which could be due to the fact that these first-generation cephalosporins are extensively used in the therapy of several bacterial infections across agricultural, veterinary, and medical sectors. ${ }^{23-25}$ Similarly, peak resistance rates were observed against Amoxicillin (95\%). This substantiates the

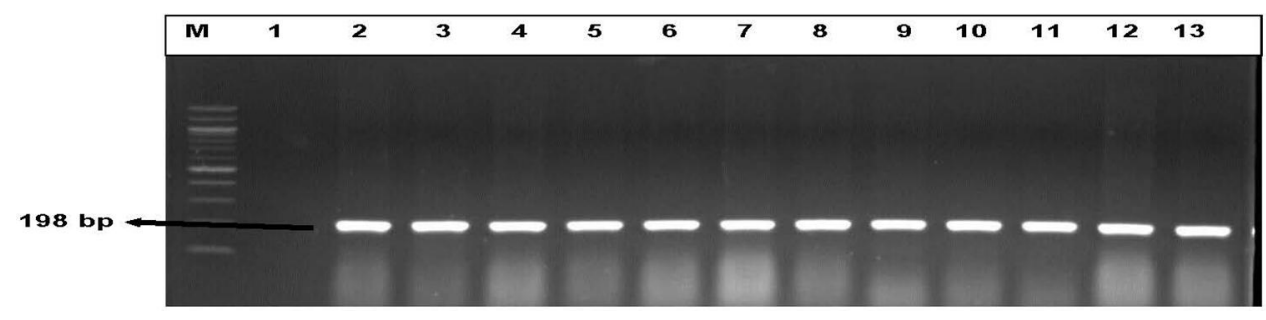

Figure $3 \mathrm{Gel}$ electrophoresis representation of $\beta$-Lactam resistance genes ampC (198 bp) detected in DEC and Salmonella isolates. Lane (M) Molecular weight marker ( 100 bp DNA ladder, Thermo Scientific), lane I: negative control, lane 2 to 13: some of the representatives of the genetic expression of ampC (I98 bP) from the $\beta$ - Lactams resistant DEC and Salmonella isolates. 


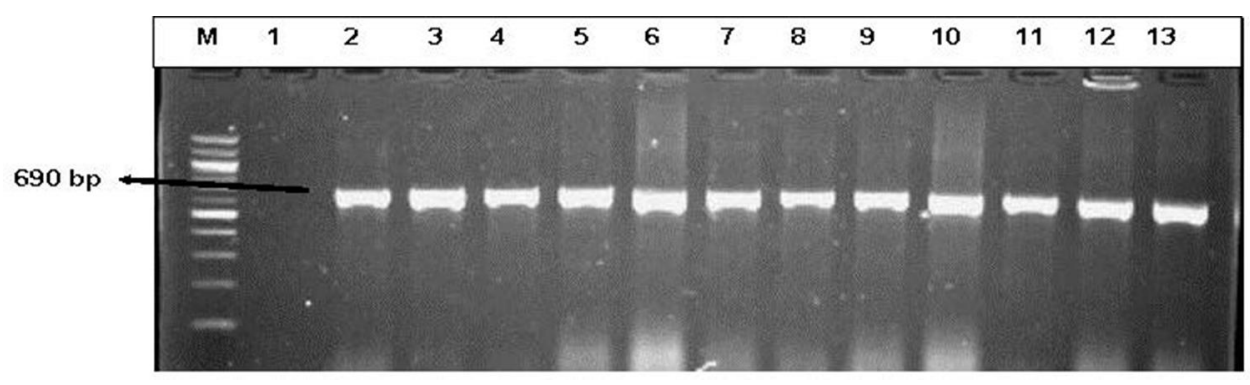

Figure $4 \mathrm{~A}$ representative gel electrophoresis profile of some $\beta$ - Lactam resistant genes detected in DEC and Salmonella isolates. Lane (M) molecular weight marker (I00 bp DNA ladder, Thermo Scientific), lane I: negative control, lane 2 to I3: some of the representatives of the genetic expression of bla TEM (690 bP) from the $\beta$-Lactams -resistant DEC.

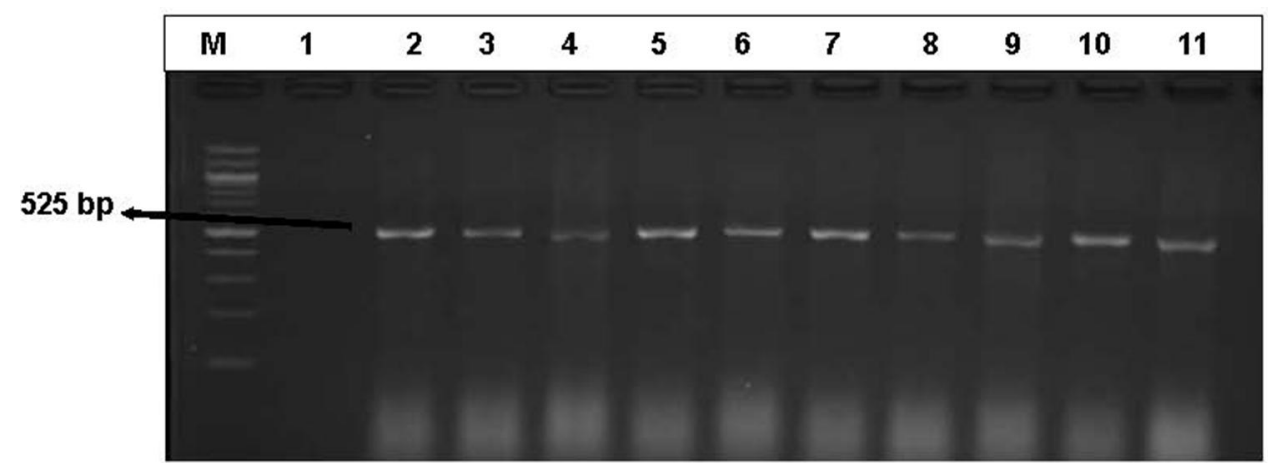

Figure 5 An illustrative gel electrophoresis image with the genetic expression of the aadA (525 bp) resistant gene among the aminoglycosides-resistant DEC and Salmonella isolates. Lane (M) molecular weight marker (100 bp DNA ladder, Thermo scientific), lane I: negative control, lane 2 to II: some of the representatives of the genetic expression of aadA (525 bp) from aminoglycoside-resistant DEC and Salmonella isolates.

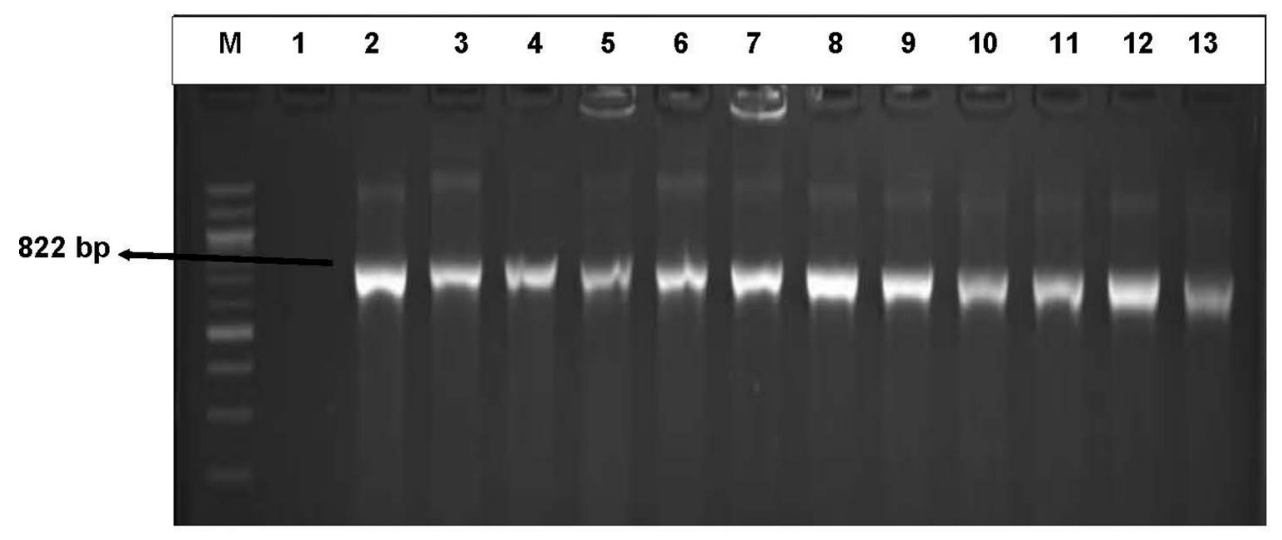

Figure 6 An illustrative gel electrophoresis image for the detection of sull (822 bp) resistance gene from the sulfonamide-resistant DEC. Lane (M) molecular weight marker ( 100 bp DNA ladder, Thermo scientific), lane I: negative control, lane 2 to 13: some of the representatives of the genetic expression of sull (822 bp) from the sulfonamideresistant DEC.

fact that; amoxicillin is the most essential antibiotics used to treat a broader range of bacterial infections (including Salmonella infections) and the most administered antibiotic in children, thus suggesting an elevated use of this drug, and consequently resulting in high resistance rates and a severe threat to public health. ${ }^{26,27}$

Antimicrobial resistance in Salmonella could be induced by the imprudent use of these antimicrobials in food-producing animals and eventually spread to humans via the intake of food and animal products or through contact with these animals. ${ }^{28}$ Though some resistance rates were considerably low in Salmonella isolates, they, however, suggest a possible resistance development over time with the continued drug misuse across different sectors which remains a serious burden of public health importance. $^{4}$ 


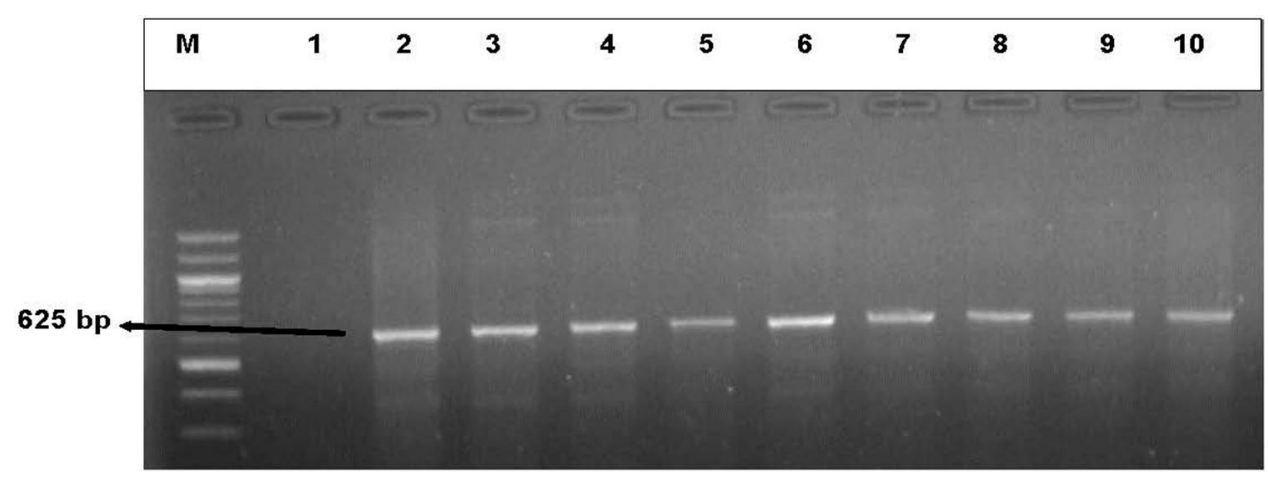

Figure 7 An illustrative gel electrophoresis for the detection of sull (625 bp) resistance gene. Lane (M) molecular weight marker (I00 bp DNA ladder, Thermo scientific), lane I: negative control, lane 2 to I0: some of the representatives of the genetic expression of sulll (625 bP) from the sulfonamide-resistant DEC and Salmonella isolates.

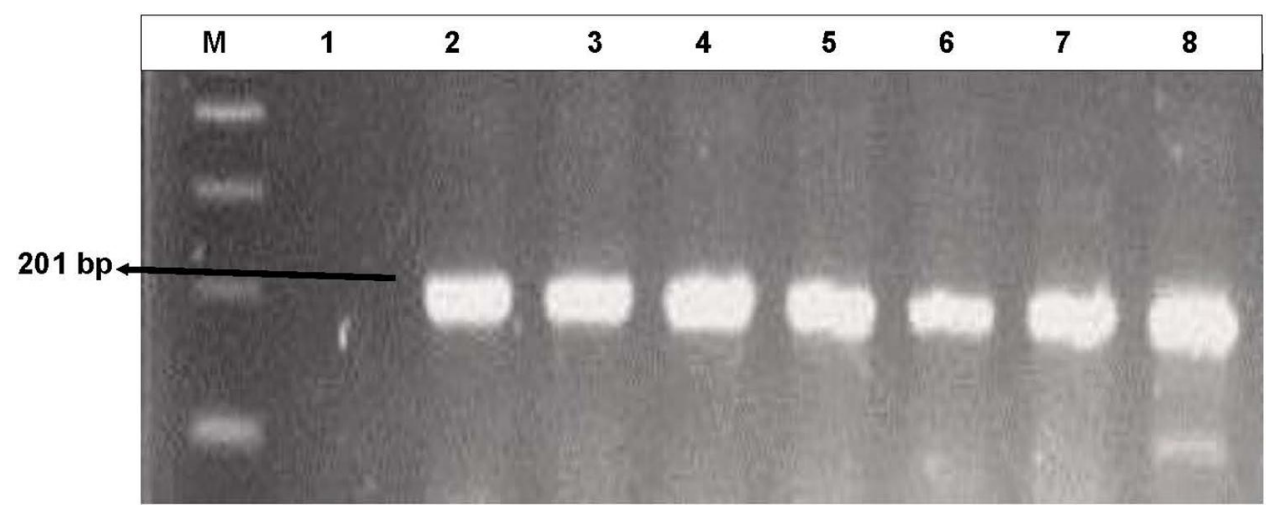

Figure 8 A representative gel electrophoresis image for the detection tet A (20I bp) resistance gene determinants. Lane (M) molecular weight marker (I00 bp DNA ladder, Thermo scientific), Lane I: negative control, Lane 2 to 8 : some of the representatives of the genetic expression of tet A (20I bP) from the Tetracycline-resistant DEC isolates.

The administration of antibiotics for treatment of diarrheal illnesses is highly acknowledgeable, however, the emergence of Antimicrobial-Resistant Enteric Bacterial Pathogens (AREBP) has become a huge setback as far as the treatment of these illnesses is concerned, which poses a serious public health burden. ${ }^{29}$ Conversely, mal-administration and inapt use of these antimicrobials in humans, agricultural sectors and veterinary medicine remain as one of the major factors, which stimulate antimicrobial drug resistance (ADR) by bacteria, adding to the burden of clinical therapeutic health systems. ${ }^{6}$ The multiple antimicrobial resistance indices (MARIs) of DEC and Salmonella isolates obtained in this study were high above the acceptable threshold of 0.2 , thus suggesting that these isolates originated from environmental sources and also suggests excessive use of these antimicrobials in the region. Moreover, the MARPs revealed in this study corroborate those of previous studies. ${ }^{12,30,31}$ Furthermore, this study confirms the incidences of over 6 antimicrobial resistance determinants, which complies with the findings of the previous report by Titilawo et $\mathrm{al}^{12}$ in which over 19 antimicrobial resistance determinants were confirmed among environmental isolates, thus suggesting possible dissemination of these genetic factors in the environment.

Considering the ecological milieus of the Amathole District Municipality, which comprises rural hinterlands with a relatively high populace of over 880790 thousand people and covers approximately $12 \%$ of the overall population of the province. Local dwellers in the province have practised communal farming for over hundreds of years, where they raise their livestock within their communities, upholding constant/close contact with their livestock, which exposes them to high risk of zoonotic transmission of antibiotic-resistant bacterial pathogens. Several studies have also acknowledged animals as the potential sources of Foodborne Antimicrobial-Resistant Bacterial Pathogens (FARBP) such as Salmonella, E. coli, Campylobacter, and other enteric pathogens. ${ }^{32-38}$ Similarly, in the present study; multidrug-resistant Salmonella and DEC isolates were recovered from patients residing in the rural hinterlands of the ADM. 
In light of the introduction of commercial farming ie dairy farming, poultry, crop farming which extends to these communities, studies have shown an upsurge burden of diseases associated with antimicrobial-resistant pathogens. This can be due to the fact that majority of these farm industries utilizes antibiotics on their farm animals for prophylaxis and to aid in the growth and development of farm animals. Additionally, inappropriate application of pesticides in crop farming promotes the tolerance and resistance by microorganisms in these environments. ${ }^{39}$

In a study by Igbinosa, ${ }^{34}$ key beta-lactams resistance factors ( $b l a_{T E M}$ and $\left.b l a_{a m p C}\right)$ were detected among Salmonella isolates. Similarly, we detected the antimicrobial resistance factors in the present study, where an average percentage of the confirmed Salmonella isolates harboured these genes.

$B l a_{T E M}$ was the predominantly detected resistance determinant among DEC isolates obtained in this study, with an average of $33 \%$ of the isolates harboured this resistance factor, which corroborates the study conducted by Zhou et $\mathrm{al}^{40}$ in the central region of China.

Among the Tetracyclines, which has over 50 different classes of tet resistance genes identified, ${ }^{41}$ class A (tet $A$ ) was remarkably the only detected class among the Tetracycline-resistant DEC isolates recovered in the present study. Plethora of incidences of tet $A$ along with sulI resistance factors have been previously implicated in environmental samples in different parts of the world. ${ }^{42,43}$ However, the clinical samples recruited in the present study also exhibited a high incidence of tet $A$ and sulI resistance genes, which alludes that; the patients may have directly or indirectly contracted the pathogens from environmental sources such as rivers, streams, lakes, etc. These findings, therefore, coincide with the rural environs of the District Municipality, as the populaces rely on surface waters for drinking, cooking and other dayto-day activities.

Similar reports highlight the environment as an imperative component for the transmission of antimicrobialresistant bacteria and the dissemination of resistance factors. Likewise, they promote the absolute need for comprehensive synopsis of the evolutionary and ecological progressions that lead to the clinical manifestation of resistance genes. Numerous reports advocate the global all-inclusive OneHealth approach to ameliorate the emergence and dissemination of antimicrobial resistance. ${ }^{44-47}$

The overall proportions of phenotypic resistance of DEC and Salmonella isolates observed against different classes of antimicrobials recruited in this study were inversely comparative to the genotypic profile of the antimicrobial resistance factors detected thereof. This suggests that; the resistance profiles elucidated among these isolates may be susceptible to diverse additional mechanisms of antimicrobial resistance such as drug efflux pump systems, integrons and gene cassettes, quorum sensing and microbial biofilm formation and so forth ${ }^{48-51}$ hence the discrepancies.

As a means of preventing further upsurge on the burden of antimicrobial resistance, several interventions have suggested the discontinued antibiotic overuse as one of the first steps in preventing further escalation of antimicrobial resistance, which may present a disastrous therapeutic and public health burden in the near future. Alternatively, urgent development of new and better effective antimicrobials are necessary, however, this development forlornly excludes some countries as this approach has been reportedly costly. This further suggests that several countries will not benefit from this even though these countries are the most affected by the endemic disease due to lack of sufficient basic resources. More controlled approaches on the distribution of antibiotic prescriptions for various uses in different sectors such as medicine, agriculture, veterinary and industrial productions are desirable, as these divisions tend to greatly affiliate to the increased antimicrobial resistance burden due to inappropriate use of these antimicrobials. Moreover, basic services such as the provision of proper sanitation tools and the supply of safe water for various purposes in underprivileged societies may aid in alleviating microbial infections since these microbes are ubiquitous in nature and most of them can be transferred through food and water and to ease the public health burden in our communities.

\section{Conclusion}

The findings of this study demonstrate bacterial coinfection of the multiple antimicrobial-resistant DEC and Salmonella species as etiologic agents of gastroenteritis, and to our best knowledge, this is a maiden study that explores the antibiogram profiles of $E$. coli and Salmonella pathogens associated with gastroenteritis patients in the region. The multiple antimicrobial resistance profiles and the relevant antimicrobial resistance factors detected among the recovered DEC and Salmonella isolates in this study indicates the inapt use of antimicrobials in the region and the transmission of resistance factors in the environment, thus posing a portentous threat to public health and a major hindrance 
in medicine. In the understanding of this, there is need for intensive surveillance systems focused on tracking the resistance patterns of antimicrobial resistant DEC and Salmonella pathogens circulating in different niches in South Africa. Also, the implementation of the holistic global one-health approach to the intensifying antimicrobial-resistance menace is highly commendable in assuaging the therapeutic and public health burden presented by these pathogens.

\section{Data Sharing Statement}

The datasets used and/or analyzed in present study will be made available on reasonable request.

\section{Ethics Approval and Consent to Participate}

This study was approved by the University of Fort Hare Research Ethics Committee and endorsed by the Department of Health, Eastern Cape, South Africa.

The permission to collect patient's stool specimen was obtained from the patients through verbal informed consent (acceptable and approved by the University of Fort Hare Research Ethics Committee) with the adult participants and parents/legal guardians or caregivers of the enrolled children, subject to detailed clarification of the study protocols. Anonymity of patient's records (names, identity or social security numbers) was highly maintained and all the research protocols of this study were conducted in accordance with the Ethical Guideline of the Declaration of Helsinki.

\section{Acknowledgments}

We would like to thank the South African Medical Research Council and the National Research Foundation for the financial support. This report is part of a database of PhD Dissertation of the first author registered at the University of Fort Hare.

\section{Disclosure}

The authors declare that they have no conflicts of interest.

\section{References}

1. Okeke IN, Sosa A. Antibiotic resistance in Africa-discerning the enemy and plotting a defence. Afr Health. 2003;25(3):10-15.

2. Centers for Disease Control and Prevention. Antibiotic: antimicrobial Resistance. http:/wwwdc.gov/drugresistance/index.html. 2018.

3. de Been M, Lanza VF, de Toro M, et al. Dissemination of cephalosporin resistance genes between Escherichia coli strains from farm animals and humans by specific plasmid lineages. PLoS Genet. 2014;10(12):e1004776.
4. Okeke IN, Laxminarayan R, Bhutta ZA, et al. Antimicrobial resistance in developing countries. Part I: recent trends and current status. The Lancet Infectious Diseases. 2005;5(8):481-493. doi:10.1016/ S1473-3099(05)70189-4

5. Richardson LA. Understanding and overcoming antibiotic resistance. PLoS Biol. 2017;15(8):e2003775. doi:10.1371/journal.pbio.2003775

6. Adesoji AT, Ogunjobi AA. Detection of extended spectrum beta-lactamases resistance genes among bacteria isolated from selected drinking water distribution channels in south-western Nigeria. Biomed Res Int. 2016;2016.

7. AMGDS. The Amathole Municipality Growth and Development Summit; 2018.

8. Eastern Cape Socio Economic Consultative Council (ECSECC) Amatole district municipality socio economic review and outlook, 2017. Available at https://www.ecsecc.org/documentrepository/informationcentre/amat hole-district-municipality_74397.pdf. Accessed December 10, 2020.

9. Gomba A, Chidamba L, Korsten L. Prevalence and serovar diversity of Salmonella spp. in primary horticultural fruit production environments. Food Control. 2016;69:13-19. doi:10.1016/j.foodcont.2016.04.026

10. Chigor VN, Umoh VJ, Smith SI, Igbinosa EO, Okoh AI. Multidrug resistance and plasmid patterns of Escherichia coli $\mathrm{O} 157$ and other E. coli isolated from diarrhoeal stools and surface waters from some selected sources in Zaria, Nigeria. Int J Environ Res Public Health. 2010;7(10):3831-3841. doi:10.3390/ijerph7103831

11. Gugliandolo C, Lentini V, Spanò A, Maugeri TL. Conventional and molecular methods to detect bacterial pathogens in mussels. Lett Appl Microbiol. 2011;52(1):15-21. doi:10.1111/j.1472-765X.2010.02959.x

12. Titilawo Y, Obi L, Okoh A. Occurrence of virulence gene signatures associated with diarrhoeagenic and non-diarrhoeagenic pathovars of Escherichia coli isolates from some selected rivers in South-Western Nigeria. BMC Microbiol. 2015;15(1):204.

13. Oueslati W, Rjeibi MR, Mhadhbi M, Jbeli M, Zrelli S, Ettriqui A. Prevalence, virulence and antibiotic susceptibility of Salmonella spp. strains, isolated from beef in Greater Tunis (Tunisia). Meat Sci. 2016;119:154-159. doi:10.1016/j.meatsci.2016.04.037

14. Jawad AA, Al-Charrakh AH. Outer membrane protein C (ompC) gene as the target for diagnosis of Salmonella species isolated from human and animal sources. Avicenna J Med Biotechnol. 2016;8(1):42.

15. Clinical Laboratory Standard Institute (CLSI). Performance Standards for Antimicrobial Susceptibility Testing. 28th ed. Wayne, PA: Clinical and Laboratory Standards Institute; 2018.

16. Kinge CNW, Ateba CN, Kawadza DT. Antibiotic resistance profiles of Escherichia coli isolated from different water sources in the Mmabatho locality, Northwest Province, South Africa. S Afr J Sci. 2010;106(1/2):44-49. doi:10.4102/sajs.v106i1/2.14

17. Blasco MD, Esteve C, Alcaide E. Multiresistant waterborne pathogens isolated from water reservoirs and cooling systems. $J \mathrm{Appl}$ Microbiol. 2008;105(2):469-475. doi:10.1111/j.13652672.2008.03765.x

18. Srinivasan V, Gillespie BE, Lewis MJ, et al. Phenotypic and genotypic antimicrobial resistance patterns of Escherichia coli isolated from dairy cows with mastitis. Vet Microbiol. 2007;124(3-4):319-328. doi:10.1016/j.vetmic.2007.04.040

19. Bailey JK, Pinyon JL, Anantham S, Hall RM. Commensal Escherichia coli of healthy humans: a reservoir for antibiotic-resistance determinants. J Med Microbiol. 2010;59 (11):1331-1339. doi:10.1099/jmm.0.022475-0

20. Maynard C, Bekal S, Sanschagrin F, et al. Heterogeneity among virulence and antimicrobial resistance gene profiles of extraintestinal Escherichia coli isolates of animal and human origin. $J$ Clin Microbiol. 2004;42(12):5444-5452.

21. Falbo V, Carattoli A, Tosini F, Pezzella C, Dionisi AM, Luzzi I. Antibiotic resistance conferred by a conjugative plasmid and a class I integron in Vibrio cholerae O1 El Tor strains isolated in Albania and Italy. Antimicrob Agents Chemother. 1999;43(3):693-696. doi:10.1128/AAC.43.3.693 
22. Ng L-K, Martin I, Alfa M, Mulvey M. Multiplex PCR for the detection of tetracycline resistant genes. Mol Cell Probes. 2001;15 (4):209-215. doi:10.1006/mcpr.2001.0363

23. Hameed TK, Robinson JL. Review of the use of cephalosporins in children with anaphylactic reactions from penicillins. Canadian $J$ Infect Dis Med Microbiol. 2002;13(4):253-258.

24. Greenwood D. Antimicrobial Drugs: Chronicle of a Twentieth Century Medical Triumph. Oxford University Press; 2008:21.

25. Harris G Citing drug resistance, US restricts more antibiotics for livestock. New York Times. Retrieved from http://www.nytimes. com/2012/01/05/health/policy/fda-restricts-use-of-antibiotics-inlivestock.html. Accessed December 10, 2020. 2012

26. McDonagh JE, Kelly DA. Adolescence and Transition to Adult Care. Diseases of the Liver and Biliary System in Children. Hoboken, NJ: Wiley-Blackwell; 2008:599-613.

27. The American Society of Health-System Pharmacists (ASHSP). 2015. - amoxicillin\|; 2017.

28. Chinwe JI Prevalence and antibiogram of some swine associated Shiga toxin producing Escherichia coli Serogroups and Salmonella species in Nkonkobe Municipality, Eastern Cape Province, South Africa (Doctoral dissertation, University of Fort Hare).

29. Tekleab AM, Asfaw YM, Weldetsadik AY, Amaru GM. Antibiotic prescribing practice in the management of cough or diarrhea among children attending hospitals in Addis Ababa: a cross-sectional study. $<![C D A T A[P e d i a t r i c$ Health, Medicine and Therapeutics]] $>$. 2017;8:93. doi:10.2147/PHMT.S144796

30. Paul S, Bezbaruah RL, Roy MK, Ghosh AC. Multiple antibiotic resistance (MAR) index and its reversion in Pseudomonas aeruginosa. Lett Appl Microbiol. 1997;24(3):169-171. doi:10.1046/ j.1472-765X.1997.00364.X

31. Olaniran AO, Naicker K, Pillay B. Antibiotic resistance profiles of Escherichia coli isolates from river sources in Durban, South Africa. World J Microbiol Biotechnol. 2009;25(10):1743. doi:10.1007/ s11274-009-0071-x

32. Marshall BM, Levy SB. Food animals and antimicrobials: impacts on human health. Clin Microbiol Rev. 2011;24(4):718-733. doi:10.1128/ CMR.00002-11

33. Wegener HC. Antibiotic Resistance-linking Human and Animal Health. In Improving Food Safety Through a One Health Approach: Workshop Summary. National Academies Press; 2012.

34. Igbinosa IH. Prevalence and detection of antibiotic-resistant determinant in Salmonella isolated from food-producing animals. Trop Anim Health Prod. 2015;47(1):37-43. doi:10.1007/s11250-014-0680-8

35. Greig J, Rajić A, Young I, Mascarenhas M, Waddell L, LeJeune J. A scoping review of the role of wildlife in the transmission of bacterial pathogens and antimicrobial resistance to the food chain. Zoonoses Public Health. 2015;62(4):269-284. doi:10.1111/zph.12147

36. Economou V, Gousia P. Agriculture and food animals as a source of antimicrobial-resistant bacteria. Infect Drug Resist. 2015;8:49. doi:10.2147/IDR.S55778

37. Doyle ME. Multidrug-resistant pathogens in the food supply. Foodborne Pathog Dis. 2015;12(4):261-279. doi:10.1089/fpd.2014.1865
38. Heredia N, García S. Animals as sources of food-borne pathogens: A review. Animal Nutrition. 2018;4(3):250-255. doi:10.1016/j. aninu.2018.04.006

39. Ramakrishnan B, Venkateswarlu K, Sethunathan N, Megharaj M. Local applications but global implications: can pesticides drive microorganisms to develop antimicrobial resistance? Sci Total Environ. 2019;654:177-189. doi:10.1016/j.scitotenv.2018.11.041

40. Zhou Y, Zhu X, Hou H, et al. Characteristics of diarrheagenic Escherichia coli among children under 5 years of age with acute diarrhea: a hospital based study. BMC Infect Dis. 2018;18(1):63. doi:10.1186/s12879-017-2936-1

41. Wang S, Gao X, Gao Y, et al. Tetracycline resistance genes identified from distinct soil environments in China by functional metagenomics. Front Microbiol. 2017;8:1406. doi:10.3389/ fmicb.2017.01406

42. Makowska N, Koczura R, Mokracka J. Class 1 integrase, sulfonamide and tetracycline resistance genes in wastewater treatment plant and surface water. Chemosphere. 2016;144:1665-1673. doi:10.1016/ j.chemosphere.2015.10.044

43. Yan M, Xu C, Huang Y, Nie H, Wang J. Tetracyclines, sulfonamides and quinolones and their corresponding resistance genes in the Three Gorges Reservoir, China. Sci Total Environ. 2018;631-632:840-848. doi:10.1016/j.scitotenv.2018.03.085

44. Nguyen-Viet H, Chotinun S, Schelling E, et al. Reduction of antimicrobial use and resistance needs sectoral-collaborations with a One Health approach: perspectives from Asia. Int $J$ Public Health. 2017;62:3-5.

45. Bengtsson-Palme J, Kristiansson E, Larsson DGJ. Environmental factors influencing the development and spread of antibiotic resistance. FEMS Microbiol Rev. 2018;42(1):fux053. doi:10.1093/ femsre/fux 053

46. Collignon PJ, McEwen SA. One health-its importance in helping to better control antimicrobial resistance. Tropical Med Infect Dis. 2019;4(1):22. doi:10.3390/tropicalmed 4010022

47. Thakur S, Gray GC. The mandate for a global "one health" approach to antimicrobial resistance surveillance. Am J Trop Med Hyg. 2019;100(2):227. doi:10.4269/ajtmh.18-0973

48. Munita JM, Arias CA. Mechanisms of antibiotic resistance. Virulence Mechanisms Bacterial Pathogens. 2016;22:481-511.

49. Strugeon E, Tilloy V, Ploy M-C, Da Re S. The stringent response promotes antibiotic resistance dissemination by regulating integron integrase expression in biofilms. MBio. 2016;7(4):e00868. doi:10.1128/mBio.00868-16

50. Lacotte Y, Ploy M-C, Raherison RS. Class 1 integrons are low-cost structures in Escherichia coli. ISME J. 2017;11(7):1535-1544. doi:10.1038/ismej.2017.38

51. Zhao X, Yu Z, Ding DT. Quorum-Sensing Regulation of Antimicrobial Resistance in Bacteria. Microorganisms. 2020;8 (3):425. doi:10.3390/microorganisms 8030425
Infection and Drug Resistance

\section{Publish your work in this journal}

Infection and Drug Resistance is an international, peer-reviewed openaccess journal that focuses on the optimal treatment of infection (bacterial, fungal and viral) and the development and institution of preventive strategies to minimize the development and spread of resistance. The journal is specifically concerned with the epidemiology of antibiotic resistance and the mechanisms of resistance development and diffusion in both hospitals and the community. The manuscript management system is completely online and includes a very quick and fair peerreview system, which is all easy to use. Visit http://www.dovepress.com/ testimonials.php to read real quotes from published authors. 